\title{
40-YEAR BIBLIOMETRIC ANALYSIS OF WAQF: ITS CURRENT STATUS AND DEVELOPMENT, AND PATHS FOR FUTURE RESEARCH
}

\author{
Khaled Nour Aldeen \\ Damascus University, Syria, khaled.knd@hotmail.com
}

\begin{abstract}
Waqf (Islamic endowment) has received great attention from contemporary scholars, in line with the increasing attention being paid to social welfare. However, it is conceptually unclear, with no consensus having been reached among researchers on its current status. This study provides a brief overview of recent Waqf research developments, hence paving the way for future research. The research employs a bibliometric approach to analysing and summarising the trends and status quo in Waqf growth. Only articles written in English extracted from both the Web of Science and Scopus databases were considered for the study. The paper is an attempt to establish a solid conceptual base and to suggest directions for future research. The research provides a clear picture of the growth of Waqf, and indicates research gaps by reaching comprehensive conclusions about what has been achieved in the field. It hence opens new doors for scholars to develop innovative Waqf models to bridge socioeconomic issues. Our findings show that Indonesian and Malaysian scholars and their educational institutions have had a robust research commitment to the theme of Waqf during the last forty years. However, there is a lack of research on the countries where Waqf was first practised.
\end{abstract}

Keywords: Sustainable philanthropy, Waqf (endowment), socioeconomic, Islamic economics and finance.

JEL Classification: I30; I31; P36.

Article history:

Received : October 1, 2020

Revised : January 7, 2021

Accepted : : February 8, 2021

Available online : February 28, 2021

https://doi.org/10.21098/jimf.v7i1.1308 


\section{INTRODUCTION}

\subsection{Background}

Islamic finance and economics have been developing quickly in recent decades. In the socioeconomics field, several countries are competing to improve the wellbeing of their population. Indonesia, Malaysia and Saudi Arabia, as Muslim majority countries, have paid significant attention to Islamic social finance instruments, as well as Singapore and Nigeria, Muslim minority countries (Aldeen et al ., 2020). Islamic finance instruments are not limited to the material profit that can be achieved in life (Dunia) but mainly consider the hereafter (Akhira), which is the ultimate goal of Muslims (Kahf, 1999). On the other hand, the mainstream economy is by nature materialistic and based on greed, which is the fundamental difference between Islamic and conventional economics. The latter was created by humans, hence it is the subject of being use against them . The key explanation for the high regard which has been granted to Islamic economics and finance over the past few decades is its power, consistency and efficiency in uplifting human prosperity by minimising deprivation and exploitation, rather than maximising social welfare (Aydin, 2020). Therefore, the role of contemporary scholars is crucial in exploring Islamic social finance instruments and models (Aldeen et al., 2020).

Waqf is a social fund politically and is free of charge. It acts as one of the core Islamic instruments in poverty alleviation by providing the basic needs for social welfare enhancement and facilitating societal growth (Kahf, 1999; Aliyu, 2019). Apart from the link between mankind and Allah (SWT), Waqf is also associated with community affairs in the spirit of mutual love, cooperation and brotherhood (Sulaiman et al., 2019). According to Abdullah (2018), welfare indicators include clothing, sufficient food, health maintenance, shelter, the feeling of being treated equitably in life, and the educational achievement of children, all of which should be efficiently addressed by Waqf institutions. Furthermore, Waqf has performed well in the area of the assurance of the five essentials (Al-Daruriyaat al-Khams) (Alam et al., 2018; Kahf, 1999). It is powerful, permanent, and pervasive since it is a cardinally voluntary activity characterised by perpetuity. Interestingly, throughout the last decade, understanding of the need for Waqf has been revitalised amongst Muslim nations, and Waqf institutions have arisen and come to prominence. For example, Sri Lanka, Sudan, and Indonesia were among the main countries that realised the importance of the Waqf revival to raise living standards. The Indonesian government has made significant reforms in the revitalisation of Waqf institutions by enacting a new Waqf act to control related institutions in Indonesia (Ihsan \& Ibrahim, 2011); for instance, Waqf act No. 41\2004 to regulate and reform Waqf entities in Indonesia (Prihatini et al., 2005). Nevertheless, this was not sufficient to regulate all Waqf assets in Indonesia (Ihsan \& Ibrahim, 2011).

Due to the efforts of contemporary researchers, Waqf concerns have taken an important position, demonstrating the advantages associated with Waqf, including its implications in societiy. Besides, it tackles the emerging challenges, mainly poverty alleviation (Aldeen et al., 2020). Most of the research reviewed emphasises that Waqf is an important tool that can be employed as an alternative against poverty, and as such the effort requires a considerable amount of financing that governments cannot fully provide. Therefore, it is unavoidable to seek a sustainable source of funds to resolve the emerging problems. Several researchers 
have attempted to review the Waqf literature, such as Hassan et al. (2020), Aldeen et al. (2020), Atan and Johari (2017) and Mokhtar et al. (2008). However, none of them were able to provide a graphically detailed illustration of the available related literature. For example, Aldeen (2020) concentrated on cash Waqf literature, excluding other types of Waqf, while Atan and Johari (2017) reviewed Waqf literature focusing on one pivotal aspect, namely poverty alleviation. Nevertheless, the potential of Waqf could be extended beyond poverty alleviation. Hence, this study intends to provide an alluded picture of the available literature, focusing on two main databases and employing a bibliometric approach.

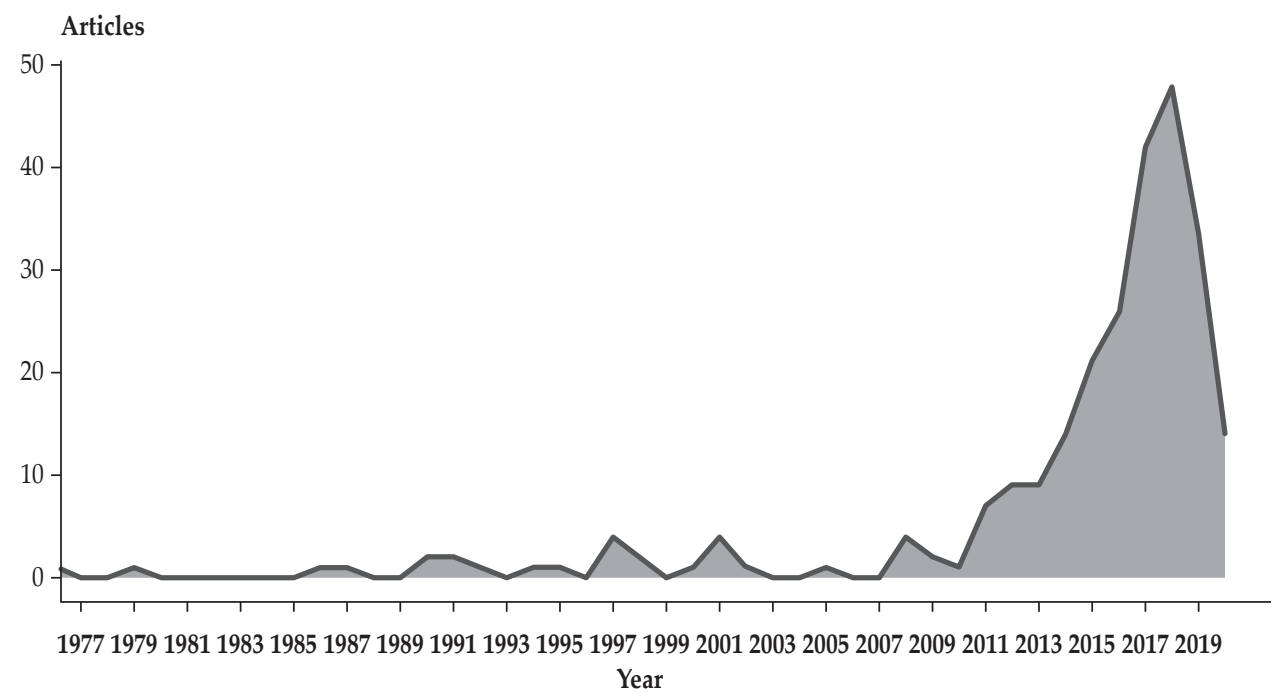

Figure 1 .

Annual Scientific Production

\subsection{Objective}

Through a bibliometric literature review, this study extends the previous work of Hassan et al. (2020), Aldeen et al. (2020), Atan and Johari (2017) and Mokhtar et al. (2008) by summarising the recent related literature by exploring two databases, namely Scopus and the Web of Science, which are considered to be the two most extensive databases. Moreover, they rank academic articles in terms of total citations and productivity, hence indicating the journals' prestige, impact, and influence (Aghaei, 2013). This research intends first to create a broad overview of current scientific works. By learning from the current situation, we expect to grasp the conceptual issues, and more specifically to recognise the progress of current trends, thus indicating a useful direction for future research in this developing and important subject. Moreover, the study intends to present the development of Waqf by demonstrating the key areas it is linked to. This bibliometric review intends to concentrate on four key fields by tackling the following questions: In which scientific journals are these articles published? Where do the authors come from? Which are the core concerns of the researchers? How are the papers cited in the literature? 
The reminder of the paper is arranged as follows. The brief introduction is followed by the research methodology and the key results, and the study ends with the conclusion.

\section{LITERATURE REVIEW}

\subsection{Background Theory}

The singular Waqf (plural Awaqaf) in Arabic means to stop, maintain or to contain (Shukor, et al., 2017). From the Islamic perspective, Waqf is simply interpreted as retaining an asset (Maal), preventing its consumption and continually extracting its usufruct for the benefit of righteousness (Kahf, 1999; Wu, 2017). Fundamentally, Waqf refers to the donation of an asset (tangible or intangible) in seeking rewards from Allah (SWT) (Kahf, 2003). Waqf is fixed, and is neither repayable nor refundable. In the case of temporary Waqf, the same conditions apply during a certain period of time, and it is forbidden to dispose of it other than for its basic purpose )Mohamed (Yusef et al., 2014). In other words, Waqf is a gift that is offered continually to beneficiaries. Flashback to the legitimate (Waqf), we find that scholars have been rooted Waqf with many evidence of the Qur'an, the Sunnah (the teachings and practices of Muhammad) and the consensus. Although they do not indicate the subject of endowment directly, it urges the acts of righteousness and goodness. There is no direct verse in the Qur'an which refers to or mentions endowment (Waqf) in a strict way, but Waqf activities can be associated with many verses which indicate philanthropy and charity (Qur'an, 3:116; Qur'an,1:280; Qur'an; 2:276; Qur'an, 5:35 ; Qur'an, 2:110 Qur'an, 73 :20; Qur'an 2:261; Qur'an, 3:92; Qur'an, 2:273; Qur'an, 2:43). Qur'an stated in verse 92 in Al-i-Imran:

\section{Never will you attain the good [reward] until you spend [in the way of Allah] from that which you love.}

Furthermore, there are several Hadith which address Waqf issues in an indirect way. For instance,

"a single sadaqa closes seventy gates of evil (al-Ghazali, $n-d)$.

Typically, four parties are involved in Waqf endowment, namely Nazhir, Mawquf, Mawquf 'alaih, and Waqif, who are respectively referred to as Waqf trustees, beneficiaries, Waqf assets and endowers. Basically, Waqf procedures are based on buildings or property . Many donors are, however, unable to afford to engage in Waqf. Cash Waqf is therefore a good choice for those donors who do not have fixed assets, meaning they can contribute in the form of money, whatever the amount. Therefore, through cash Waqf, all levels of society are able to contribute to sustainable charity activities as long as they are willing to (Salleh et al., 2020). Cash Waqf activities can be classified into two different categories. The first is direct cash Waqf, in which money is channeled in order to renovate an old Waqf asset. In the second, indirect cash Waqf is invested in permissible activities then distributed as usufruct to specific beneficiaries (Mohsin, 2008). 
An essential part of Islamic socioeconomics, cash Waqf is a social fund economically and politically free of charge . Furthermore, it is permanent, powerful, and pervasive, since it is a cardinally voluntary activity characterised by perpetuity. Among the reasons for the recent comeback of Waqf in the contemporary context is its flexibility. It allows all Muslim segments to participate in Waqf activity regardless of the amount of money involved. Moreover, it is more practical to distribute its benefits among awider segment of receivers, it is uncomplicated to manage, and easy to utilise for beneficiaries' daily necessities (Abdullah Nadwi and Kroessin, 2013). Furthermore, Waqf can be used for the promotion of activities in the real sector of the economy, and for the creation of employment opportunities, production, and consumption. All these impact positively on the economic growth of a country (Aliyu, 2019). A wide range of research addresses Waqf issues and has been published in different journals, particularly in the last decade. Among the reasons for this is the advertisement of Waqf (Aldeen et al., 2020).

\subsection{Previous Studies}

Due to the international recognition of the importance of Waqf and its efficiency in addressing several socioeconomic issues, contemporary scholars have attempted to reveal the benefits associated with Waqf practices, including their application in contemporary societies and their addressing of related challenges. Kachkar (2017), for instance, presented a comprehensive model for employing cash Waqf donations to help refugees, employing both temporary and perpetual funds. Atan and Johari (2017) reviewed the Waqf literature that addresses poverty alleviation over the period 2006 to 2016, focusing on the publication year, the number of authors, and the country of study. They employed Mendeley's open-access tool to extract the related data. As in the case of several other Waqf studies, they conclude that Waqf is an efficient instrument to eradicate poverty. However, Atan and Johari's study does not provide a comprehensive conclusion about what has been done in the area. Moreover, they did not employ a clear method to retrieve the data, such as keyword searches. Therefore, in this study we attempt to expand the scope of the research in order to include all the related articles spanning the period 1977- 2019. Another attempt was made by Aldeen et al. (2020) to review the Waqf literature. However, they only reviewed the cash Waqf-related literature by employing Google Scholar to collect the related articles to achieve their thematic review goal. They concluded that contemporary scholars employed cash Waqf in order to address poverty and education related issues.

In the Malaysian context, Mokhtar et al. (2008) concluded that Waqf had wide potential to address socioeconomic issues and reduce the gap between rich and poor if its properties were managed properly. Besides, a systematic literature review conducted by Hassan et al. (2020) confirmed that Waqf land was not able to reach its potential due to the lack of Waqf trustee expertise, plus the fact that considerable capital was required to manage Waqf land in Malaysia. Furthermore, a literature review of 19 national Indonesian articles and 5 international articles addressing Waqf trustee issues was conducted by Charda (2020), who concluded that Waqf trustee competencies were not sufficient for them to act as Waqf managers. Charda emphasised that the three main skills that Waqf trustees lacked were training, 
knowledge, and expertise in higher positions. Another interesting review of online media concerns with Waqf was conducted by Syahputra and Khalid (2020), which addressed the case of Sumatra in Indonesia. The authors were concerned with three main aspects: Waqf designation, the religion of the endowers, and the character of the media. They found that Waqf land was dominant on Sumatra Island, and that cash Waqf was less highlighted in the media. Moreover, the endowers' religion was Muslim and they are invited from media which is reachable for both Muslim and non-Muslims . Nadwi and Kroessin (2013) reviewed socioeconomic and fiqh (Islamic jurisprudence) issues about cash Waqf permissibility. They stressed that the hybridisation of cash Waqf and microfinance could offer innovative ways to enhance access to development finance.

Based on the discussion above, the Waqf literature has received reasonable attention from contemporary scholars. Several scholars have concentrated on the literature to serve national purposes, such as Mokhtar et al. (2008) and Hassan et al. (2020) in the case of Malaysia, and Syahputra and Khalid (2020) in the case of Indonesia. On the other hand, a few researchers have focused only on cash Waqf, such as Aldeen et al. (2020). This study extends previous ones in the Waqf literature by presenting a clear picture of the main research topics and providing a clear graphically detailed illustration. This study differs in many aspects from previous ones. First and foremost, it provides an alluded picture of the literature between 1977-and 2019, including Waqf in both cash and traditional form. Second, the study concentrates on four elements, namely, journal distribution, keywords, authors' country of origin, and citation analysis, which are the four main goals of conducting bibliometric analysis. Hence, this research will highlight the main aspects that have been addressed in the Waqf industry. Moreover, any missing aspects will be addressed in this study .

\section{METHODOLOGY}

\subsection{Method}

Technically, bibliometric analysis employs statistical methods to quantitively assess academic journals, authors and citation rates (Pritchard, 1969). To achieve our bibliometric analysis, we focused on three main keywords and terms, namely Waqf, Islamic social finance and endowment, in order to identify all the studies related to Waqf. We also included several keywords and terms with minor variations to increase the coverage of the literature concerned, namely sustainable philanthropy and socioeconomics. The research involved the following phases:

- Selection of documents that contained the research keywords; and

- Scanning of the references cited in each paper to access more relevant literature.

Prior to the review phase, the relevancy of all the identified documents was evaluated based on their title, abstract and conclusion. Some papers were considered irrelevant to the main topic of Waqf, but were used in the next phase, which was the review of the the references lists, to search for further articles related to the subject matter. For inclusion, a piece of the document needed to comprise a substantive explanation on any of the titles that scored on the list of our results. This requirement that the selected article had to include certain information suggested its relevance to the topic of "Waqf". 


\subsection{Model Development}

The purpose of a bibliometric analysis is to assess academic articles through four main aspects, namely journal distribution, authors' country of origin, keywords and citation analysis, as done by Zhang et al. (2019) and Apriliyanti and Alon (2017). Pritchard (1969) used this method for the first time, and it has gained wide popularity to aid quantitative analysis in the understanding of literature. Taking into account the research objective, the recommendations made by Apriliyanti and Alon (2017), Zhang et al. (2019) and Alon et al. (2018) were considered thoroughly to perform the bibliometric analysis. We used R-studio software, which is an integrated development environment (IDE) for $\mathrm{R}$, a language is used for graphics programming and statistical computing (Aria and Cuccurullo, 2017).

\subsection{Selection Process}

The main purpose beyond narrowing the research question to Waqf was to end with an exhaustive summary of the current evidence relevant to the subject matter. Published studies were downloaded employing Scopus and Web of Science databases. However, only articles were considered relevance significantly to be scored as part of this result .

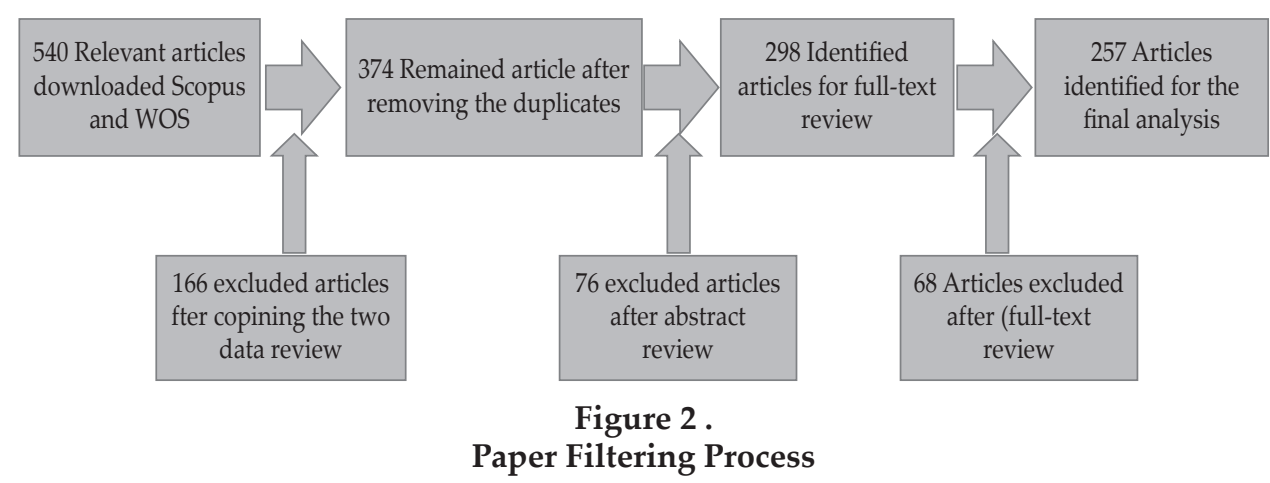

Table 1.

Main Data Informa tion (1977-2019)

\begin{tabular}{lc}
\hline Description & Result \\
\hline Sources & 117 \\
Documents & 257 \\
Average years from publication & 6.05 \\
References & 10433 \\
Articles & 228 \\
Conference papers & 29 \\
Single-authored documents & 81 \\
Multi-authored documents & 461 \\
\hline
\end{tabular}


An overall picture of the collected articles shows that 581 were relevant, out of which 540 were journal articles and conference proceedings, with the remaining documents being book chapters, reviews and other types of documents. The research only included articles written in English. We assumed that English articles were accessible by a wider audience, and non- English articles comprised only $4 \%$ of the overall selected articles. Therefore, we did not expect non-English articles would appear in the analysis, since the majority were written in English. The studies were retrieved under such criteria. After merging the datasets, a group of 374 articles related to Waqf was retrieved, after eliminating duplicate ones. 76 articles were deleted after the initial review; 298 were reviewed thoroughly and finally 257 remained for the bibliometric analysis.

\section{RESULTS AND ANALYSIS}

\subsection{Results}

In this section we address each of the research questions separately, and present all the related graphs for further illustration. Malaysia was counted among the top countries in terms of university affiliation (see Figure 3).

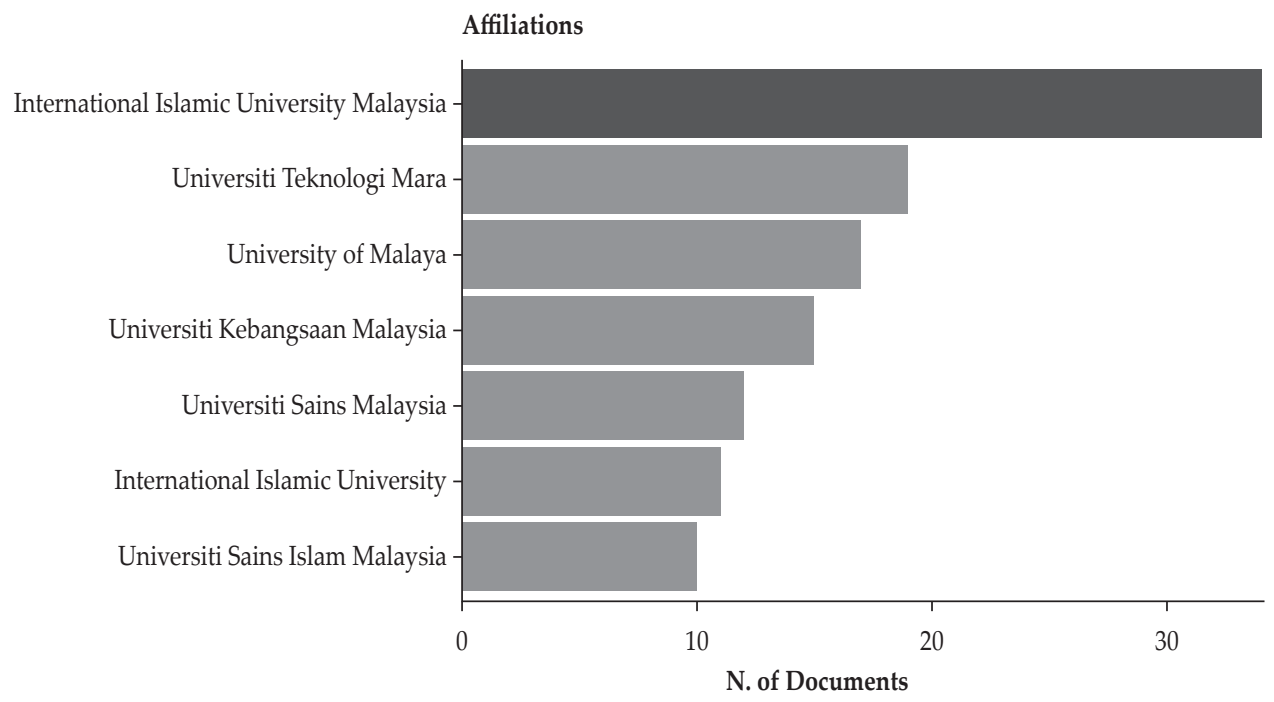

Figure 3.

The Most Relevant Affiliations (top seven)

\subsubsection{Distribution of the journals}

Table 2 includes a list of journals according to the number of their publications (in our sample, more than four articles per journal). Obviously, Waqf is defined as a key element of social finance. The main journals publishing related work tended to be those which concentrate on Islamic finance and particularly Islamic social finance, whereas the high-quality economics journals (Q1 journals) concentrate on mainstream economics studies without paying enough attention to this 
sustainable social instrument. We did find several relative journals, namely one on law and society review (Kuran, 2001), and one from Lowa Law Review (Wu, 2017). Generally, the mainstream economics journals are silent on the effectiveness of Islamic social finance issues, particularly Waqf. There are three main Islamic economics journals on the top of the list in Table 2, the Journal of King Abdulaziz University Islamic Economics, the Journal of Islamic Accounting and Business Research, and the Journal of the Economic and Social History of the Orient, which are all Islamic economics and finance field journals.

Table 2.

Journal Distribution (Main Journals with more than four Publications)

\begin{tabular}{lc}
\hline Journal & Number of papers \\
\hline JOURNAL OF KING ABDULAZIZ UNIVERSITY ISLAMIC ECONOMICS & 10 \\
JOURNAL OF ISLAMIC ACCOUNTING AND BUSINESS RESEARCH & 9 \\
JOURNAL OF THE ECONOMIC AND SOCIAL HISTORY OF THE ORIENT & 9 \\
ADVANCED SCIENCE LETTERS & 8 \\
HUMANOMICS & 8 \\
ISRA INTERNATIONAL JOURNAL OF ISLAMIC FINANCE & 8 \\
PERTANIKA JOURNAL OF SOCIAL SCIENCES AND HUMANITIES & 8 \\
GLOBAL JOURNAL AL-THAQAFAH & 7 \\
INTERNATIONAL JOURNAL OF INNOVATION CREATIVITY AND CHANGE & 7 \\
JOURNAL OF ISLAMIC ECONOMICS BANKING AND FINANCE & 7 \\
AL-SHAJARAH & 6 \\
INTELLECTUAL DISCOURSE & 6 \\
ISLAMIC LAW AND SOCIETY & 6 \\
INTERNATIONAL JOURNAL OF ISLAMIC AND MIDDLE EASTERN & 5 \\
FINANCE AND MANAGEMENT & 5 \\
MUSLIM WORLD & 4 \\
INTERNATIONAL JOURNAL OF MIDDLE EAST STUDIES & 4 \\
INTERNATIONAL JOURNAL OF PSYCHOSOCIAL REHABILITATION & 4 \\
INTERNATIONAL JOURNAL OF SOCIAL ECONOMICS & 4 \\
IOP CONFERENCE SERIES: EARTH AND ENVIRONMENTAL SCIENCE & 4 \\
JURNAL PENGURUSAN & 4 \\
\hline
\end{tabular}

\subsubsection{Authors' country of origin}

It is also worth investigating where the emphasis on Waqf articles mainly comes from. We considered at this matter by relating it to the countries of origin of the writers and their affiliations. Figure 4 gives a clear picture, showing that the main contributors to the fast growth of this field were largely from Malaysia, the US, and a few other developed countries. It is not unexpected to see the dominance of Malaysian-based researchers in this domain, as the AAIOF and many other main Islamic finance groups have their headquarters in Malaysia, a fact which can expedite and encourage relevant research. Nearly 35 authors were originally from Malaysia. Figure 4 shows that most Waqf research has been conducted in Malaysia and its educational institutions (see Figure 3). 


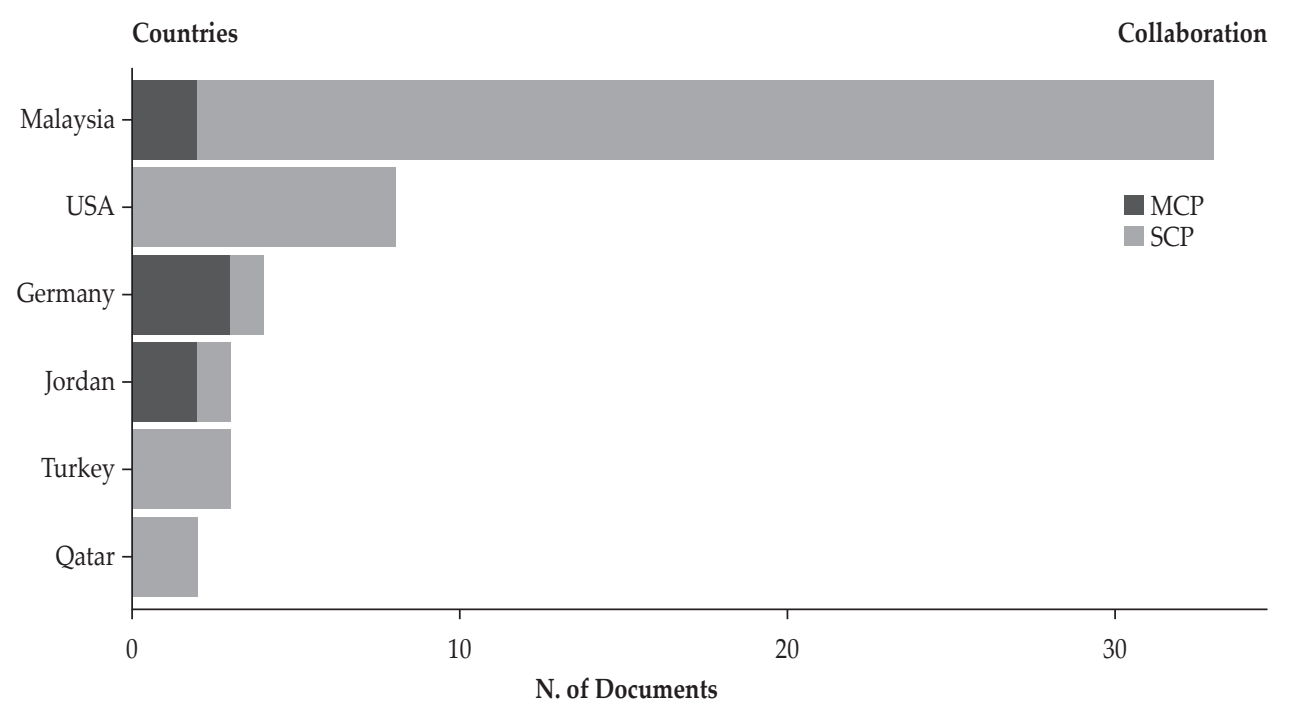

MCP: Single author manuscripts; SCP: Multiple author manuscripts.

Figure 4.

Corresponding Authors' Counties of Origin (Top Six)

\subsubsection{Keyword analysis}

Table 3 shows the top ten keywords in the literature, with cash Waqf and Malaysia among the top concerns. The high focus on cash Waqf in Malaysia could be attributed to the fatwa related to the subject declared in 2007 by Al-mujamma' al-fiqhi (Islamic Fiqh Academy) in its fifteenth meeting, which issued statement No. 140 that countersigns that cash Waqf is permissible (Raghibi \& Oubdi, 2018).

Figure 5 gives a visual overview of the keywords that feature in the study articles. Both the top word list and the graphical information provide interesting patterns. A variety of keywords are seen that have attracted the attention of contemporary scholars. For instance, 'accountability'; after the announcements of both the Malaysian and Indonesian governments, many Awaqf institutions were established (Suhaimi Nahar \& Yaacob, 2011). This attracted the researchers ' attention to address issues that can maximise Nadzir (Waqf manager) performance and to examine whether they violate the Shariah (Yaacob, 2013). Beside the core keywords, there are a number of topics studies by both mainstream and Islamic economics scholars alike. For example, poverty; Waqf in all its forms has been seen to be an effective and sustainable instrument than can efficiently assist in poverty alleviation (Sadeq, 2002; Haneef et al., 2015; Shaikh et al. 2017). 
Table 3.

Top Ten Keywords

\begin{tabular}{lc}
\hline Word & Frequency \\
\hline Waqf & 107 \\
Cash Waqf & 31 \\
Malaysia & 17 \\
Islamic finance & 11 \\
Accountability & 9 \\
Development & 6 \\
Endowment & 6 \\
Financing & 6 \\
Awqaf & 5 \\
Endowments & 5 \\
\hline
\end{tabular}

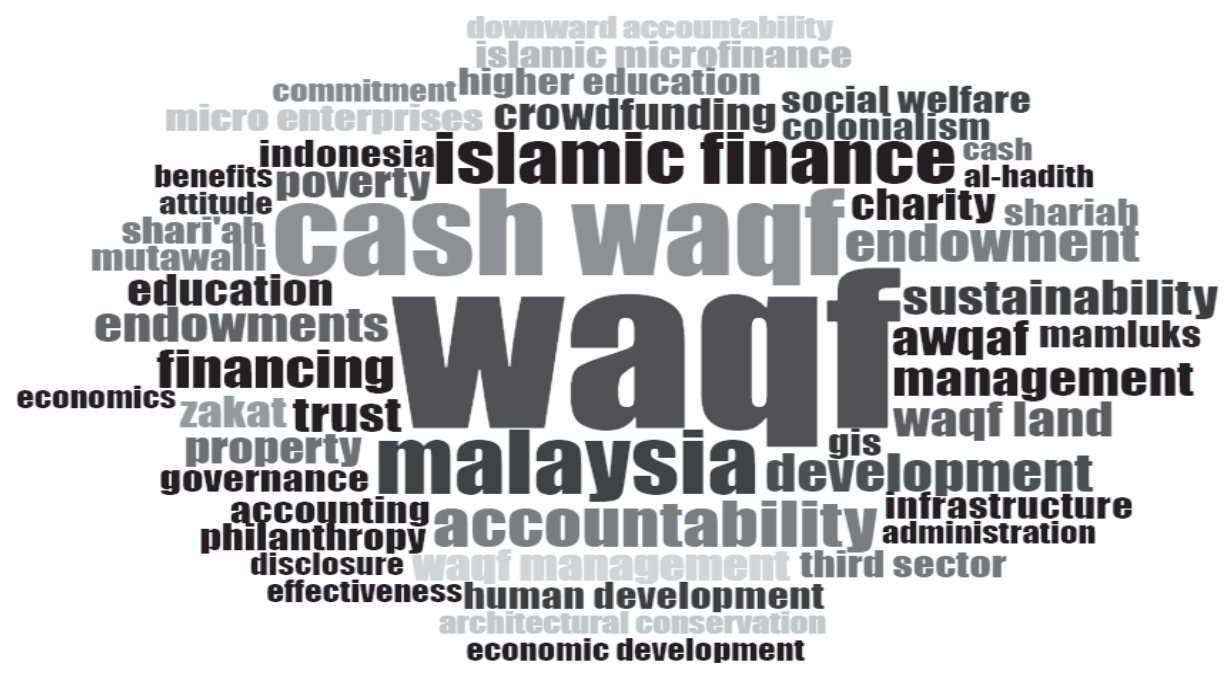

Figure 5.

Keyword Analysis

\subsubsection{Citation Analysis}

Articles on Waqf are well-cited, with the average number of citations in our sample of 257 articles being 7.6. The highest number of citations is for Kuran (2001). Table 4 illustrates the top ten cited articles, which establish that these papers come from a wide range of sources, and confirms the interdisciplinary nature of Waqf as a field of study, since it is not only journals concerned with Islamic economics that are mentioned in the list. Table 4 shows that the top cited papers are evolutionary papers, since most of them provide a concept or theory to build on. After investigating the sources of the references cited by the selected articles, these were clearly dominated by social science, arts and humanities, economics, and business and accounting journals. However, there were some articles in engineering journals, such as that of Sakti and Rani (2020), and others in environmental science journals, for instance that of Yaakob et al. (2017). 
Table 4.

Top Ten Most Cited Documents

\begin{tabular}{|c|c|c|c|}
\hline Author/year & $\begin{array}{c}\text { Total } \\
\text { Citations }\end{array}$ & Title & Journal \\
\hline Kuran (2001) & 409 & $\begin{array}{l}\text { The provision of public goods } \\
\text { under Islamic law: Origins, } \\
\text { impact, and limitations of the } \\
\text { waqf system }\end{array}$ & Law and Society Review \\
\hline Sadeq (2002) & 234 & $\begin{array}{l}\text { Waqf, perpetual charity and } \\
\text { poverty alleviation }\end{array}$ & $\begin{array}{c}\text { International Journal of Social } \\
\text { Economics }\end{array}$ \\
\hline Hoexter (1998) & 121 & $\begin{array}{l}\text { Waqf studies in the twentieth } \\
\text { century: The state of the art }\end{array}$ & $\begin{array}{c}\text { Journal of the Economic and Social } \\
\text { History of the Orient }\end{array}$ \\
\hline Mohsin (2013) & 96 & $\begin{array}{l}\text { Financing through cash-Waqf: } \\
\text { a revitalization to finance } \\
\text { different needs }\end{array}$ & $\begin{array}{c}\text { International Journal of Islamic } \\
\text { and Middle Eastern Finance and } \\
\text { Management }\end{array}$ \\
\hline Peri (1992) & 95 & $\begin{array}{l}\text { Waqf and ottoman welfare } \\
\text { policy }\end{array}$ & $\begin{array}{c}\text { Journal of the Economic and Social } \\
\text { History of the Orient }\end{array}$ \\
\hline Baer (1997) & 75 & $\begin{array}{l}\text { The Waqf as a prop for the } \\
\text { social system (Sixteenth- } \\
\text { Twentieth Centuries) }\end{array}$ & Islamic Law and Society \\
\hline Shatzmiller (2001) & 69 & $\begin{array}{l}\text { Islamic institutions and } \\
\text { property rights: The case of } \\
\text { the 'Public Good' Waqf }\end{array}$ & $\begin{array}{c}\text { Journal of the Economic and Social } \\
\text { History of the Orient }\end{array}$ \\
\hline Gil (1998) & 57 & The earliest Waqf foundations & Journal of Near Eastern Studies \\
\hline Yayla (2011) & 51 & $\begin{array}{l}\text { Operating regimes of the } \\
\text { government: Accounting and } \\
\text { accountability changes in the } \\
\text { sultan süleyman Waqf of the } \\
\text { ottoman empire (the } 1826 \\
\text { experience) }\end{array}$ & Accounting History \\
\hline Fay (1997) & 50 & $\begin{array}{l}\text { Women and Waqf: Toward a } \\
\text { reconsideration of women's } \\
\text { place in the Mamluk } \\
\text { household }\end{array}$ & $\begin{array}{l}\text { International Journal of Middle } \\
\text { East Studies }\end{array}$ \\
\hline
\end{tabular}

\subsection{Quality Assurance}

Since this is a bibliometric literature review, it is crucial to ensure the reliability of the data collected. Several criteria were considered to select articles for inclusion in the study (see Figure 2). Moreover, in the keyword analysis, most of the repeated keywords in the articles were closely related to the research topic. Therefore, we considered that the selection on the basis of two of the most popular databases, namely WOS (Web of Science) and Scopus, was sufficient to provide an alluded picture of Waqf's current status and to highlight what has been missed in the literature (see Figure 5). Furthermore, the intention was to include only articles written in English, since those not only comprised $4 \%$ of the overall relevant articles. Therefore, not including non-English articles in the study does not affect the bibliometric outcomes. 


\subsection{Analysis}

It is clear that Waqf remains of no interest to mainstream economics or finance journals. However, modern economic thought fails to address people's prosperity since it is based on wealth accumulation in a greedy way. Although the importance and urgent need for sustainable social finance tools rather than the paracetamol tools is widely perceived, much remains to be done to bring the swiftly growing topic to the consideration of mainstream economic and finance research in order to fill the wide gap in the present literature. The significant growth of Waqf research interest from recognized journals of Islamic finance (see Figure 1) could be attributed to a number of reasons. First, it is intentionally drawing awareness from societies (Siswantoro and Dewi, 2007). Therefore, the implementation of Waqf has drawn many scholars to research its potential and impacts. Second, the permissibility of the cash form enables all groups of Muslims to take part in Waqf. Third, what prompted Malaysia and Indonesia to lead research in this area was Bank Muamalat Malaysia Berhad (BMMB)'s efforts to promote such an instrument (Mokhtar et al., 2015), in addition to the new fatwas related to Awqaf activities in Malaysia and Indonesia (Aliyu, 2019). This wide consideration of Waqf practices should be considered globally because Malaysia and Indonesia are the only countries that appear in the keyword analysis (see Figure 5).

For years, Malaysia has been the most enthusiastic promoter for Islamic social finance, which could be attributed to two main reasons. First, it believes that Islamic financial activities contribute significantly to the real economy, and second, because of Islamic financial resilience during the financial crisis. These prompted the government to consider this sector active in the financial intimidation, while the majority of studies from other regions follow this up and appear later (Kassim, 2016). Among the visible contributors are Malaysia and Indonesia, considering their sizes, Muslim populations and their share of Islamic finance assets. The unbalanced distribution among the Muslim majority countries implies that Malaysia and Indonesia dominate Islamic finance, particularly Waqf products. It is obvious that research related to the subject is dominated by developing countries. However, this is likely to change in the short run due to the official recognition of Islamic finance worldwide; the authors' country of origin shows that other nationalities are interested in researching this sustainable instrument (see Figure 4). Moreover, the citation analysis shows a wide range of sources. Issues related to developed countries and their contribution to Waqf assets could be one of the principal future directions of research.

Researchers also show interest in the impact of Waqf, or how much it can contribute to development and sustainability (Abdullah, 2018; Sadeq, 2002; Shaikh et al., 2017). 17 SDG implementations are ideally compatible with the long-term Shariah objectives; moreover, there is sufficient room for Waqf partners to establish Waqf-based action strategies in accordance with the SDG framework (Mohammad Abdullah, 2018). What is more, Waqf makes a significant contribution to financing education and higher education, given the importance of education for human capital development and its impact on economic growth (Mahamood and $\mathrm{Ab}$ Rahman, 2015; Sadeq, 2002; Azha et al., 2013).

Figure 6 presents the main topics discussed in the articles included in this study; as scholars are paying much more attention to waqf and its role in poverty 
alleviation, cash Waqf is given an extra attention due to its flexibility as a cash instrument. Moreover, it allows all the segments of society to participate in Waqf. Presenting the history of Waqf is indispensable for contemporary researchers; it has been considered to be a clue to Waqf effectiveness.

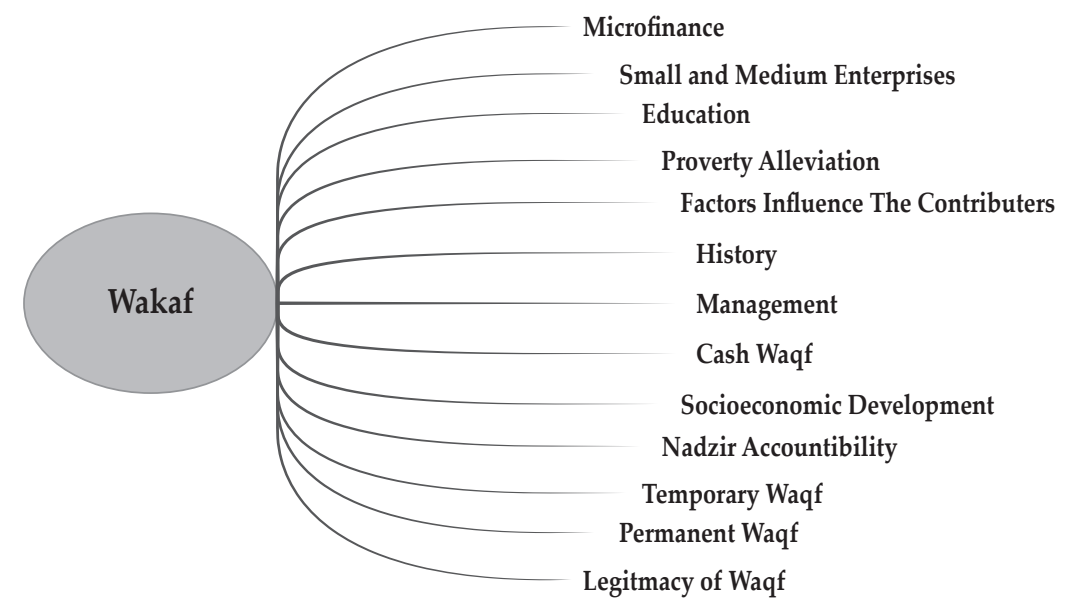

Figure 6.

Summary of Waqf Research Topics

In summary, Indonesia and Malaysia are leading the industry in terms of nations that are most likely to appear in contemporary research, although many of the authors are not originally from the two countries. That can be attributed to the related regulations and government support from Indonesia and Malaysia to enhance Waqf potential in these Muslim majority countries.

Current studies are based mainly in social science and humanities journals. Future Waqf studies should be extended and connected energy and computer due to its flexibility, especially in its cash form.

\section{CONCLUSION AND RECOMMENDATIONS}

\subsection{Conclusion}

This research employed a bibliometric approach to analyse the current status and trend development of academic research in the field of Waqf, through a ratings study and envisioned illustration of several key factors in a sample of 257 related published articles retrieved from the WOS and Scopus databases. A piece of the necessary information is found that can assist in revealing an authentic picture of the subject of Waqf.

As for the journal distribution, only those journals that are entitled to the Islamic economics domain pay reasonable attention to Waqf. Waqf studies are relatively absent in mainstream economics journals. However, it could be employed to address many of the unfavourable circumstances of mainstream economics. Regarding the authors' countries of origin analysis, this shows that 
Waqf research is mainly dominated by Malaysian authors, with Malaysia at the top of the list of country production. Articles addressing Waqf topics are mainly published in social science and humanitarian journals. Waqf research can be extended to include engineering and computing in order to enhance Waqfchain practices. With regard to the analysis of the keywords in the reviewed literature, prior to the high interest in Waqf in Indonesia and Malaysia, several countries had enjoyed a long experience of Waqf practices, such as Egypt, Iraq, Syria, Iran, Turkey, India, Pakistan, and Burma (Sayed Khalid Rashid , 2003), although there is little research on these countries. However, it vital to learn from their experience, since Waqf practices were highlighted in these countries. The current literature mainly focuses on poverty alleviation and education; however, Waqf practices could be extended to serve SDGs due to their flexibility. Models to enhance Nadzir efficiency would be highly welcomed; a wide range of research criticises Waqf managers' efficiency, so public willingness to be involved in Waqf practices will be affected positively. In view of the citation analysis, our bibliometric analysis shows that papers concerned with the theory and concept of Waqf are the most cited articles.

To the best of our knowledge, no previous research has conducted a systematic literature review that provides a holistic overview of the topic; it is highly recommended that this be explored and linked to our bibliometric results. As in any study, this paper has some limitations; for example, it only considers articles written in English, and only ones from two databases.

\subsection{Recommendations}

Waqf has shown its great importance and fast-growing relevance, with the rising interest in the recent literature (Figure1), but the lack of consideration from both developing and developed countries alike, since Malaysia and Indonesia dominate the industry, has created a gap that gives opportunities to scholars in at least three directions in future research development. First, Waqf has been proved its efficiency as a social finance instrument and in the role it plays in social prosperity. Hence, non-participating countries must take a step towards whether they increase community willingness and awareness or Nadzir efficiency. Moreover, inviting other countries will help in exchanging experiences or models that may take a long time to be developed and proved to be efficient. Second, models should be developed that serve other SDGs, rather than just poverty alleviation and education topics, since Waqf can be in form of cash, assets, or even a service, which reflect the extent to which Waqf instruments are fixable . Topics such as waqfchain, E-waqf, encrypted Waqf, and Waqf in the 4.0 era should be considered by engineering and computer science journals. Third, models should be developed that enhance the efficiency of Nadzir, since the research shows that some Waqf managers (Nadzir) lack credibility.

As for practitioners, it is advisable to stress the transparency of the Waqf institution. This will add to the credibility of Nadzir, hence increasing Waqf shares in a nation. As for the regulators, their mission should be closely linked to Waqf manager practices by ensuring a fair allocation of Waqf assets/money. Moreover, they could provide regular evaluation of Waqf entities. 
Both Muslim majority and minority countries should consider Waqf practices in the form of both cash and assets. The Malaysian and Indonesian experience could serve as a good role model in establishing the basis for Waqf practices in other countries.

\section{REFERENCES}

Abdullah, M. (2018). Waqf, sustainable development goals (SDGs) and maqasid al-shariah. International Journal of Social Economics, 45(1), 158-172. https://doi. org/10.1108/IJSE-10-2016-0295

Aghaei Chadegani, A., Salehi, H., Yunus, M., Farhadi, H., Fooladi, M., Farhadi, M., \& Ale Ebrahim, N. (2013). A comparison between two main academic literature collections: Web of Science and Scopus databases. Asian Social Science, 9(5), 1826.

Alam, M. M., Shahriar, S. M., Said, J., \& Monzur-E-Elahi, M. (2018). Waqf as a tool for rendering social welfare services in the social entrepreneurship context. Global Journal Al-Thaqafah, Special Issue, 87-98.

Aldeen, K. N., Ratih, I. S., \& Herianingrum, S. (2020). Contemporary issues on cash waqf: A review of the literature. International Journal of Islamic Economics and Finance (IJIEF), 3(2), 119-144. https://doi.org/10.18196/ijief.3236

Aliyu, S. U. (2019). Reflections on the socioecomic role of waqf in an Islamic economic system. IJUS I International Journal of Umranic Studies, 21(1), 31-43.

Alon, I., Anderson, J., Munim, Z.H., \& Ho, A. (2018). A review of the internationalization of Chinese enterprises. Asia Pacific Journal of Management, 35(3), 573-605 https://doi.org/10.1007/ s10490-018-9597-5

Apriliyanti, I.D. \& Alon, I. (2017). Bibliometric analysis of absorptive capacity. International Business Review, 26(5), 896-907, https://doi.org/10.1016/j. ibusrev.2017.02.007

Aria, M. \& Cuccurullo. C. (2017). Bibliometrix: An R-tool for comprehensive science mapping analysis. Journal of Informetrics, 11(4), 959-975.

Atan, N. A., \& Johari, F. (2017). A review on literature of waqf for poverty alleviation between 2006-2016. Library Philosophy and Practice (e-journal), 7(1), 1-31. Article number 1486. https://digitalcommons.unl.edu/libphilprac/1486/

Aydin, N. (2020). Paradigmatic foundation and moral axioms of Ihsan ethics in Islamic economics and business. Journal of Islamic Accounting and Business Research, 11(2), 288-308. https://doi.org/10.1108/JIABR-12-2016-0146

Azha, L., Baharuddin, S., Salahuddin, S. S., \& Afandi, M. R. (2013). The practice and management of waqf education in Malaysia. Procedia-Social and Behavioral Sciences, 90, 22-30. https://doi.org/10.1016/j.sbspro.2013.07.061

Baer, G. (1997). The Waqf as a prop for the social system (SixteenthTwentieth Centuries). Islamic Law and Society, 4(3), 264-297, https://doi. org/10.1163/1568519972599752

Charda, F. E. (2020). Analisis kompetensi nazhir pada lembaga wakaf: Literature review. Prosiding Hukum Ekonomi Syariah, 6(2). 1-12. http://dx.doi.org/10.29313/ syariah.v6i2.21889 
Fay, M. A. (1997). Women and waqf: Toward a reconsideration of women's place in the Mamluk household. International Journal of Middle East Studies, 29(1), 3351. https://doi.org/10.1017/S002074380006414X

Gil, M. (1998). The earliest waqf foundations. Journal of Near Eastern Studies, 57(2), 125-140. https://doi.org/10.1086/468624

Hassan, M. A. M., Alias, A., \& Mahamood, S. M. (2020). Systematic literature review of waqf land development in Malaysia. International Journal of Advanced Research in Economics and Finance, 2(2), 70-78.

Haneef, M. A., Pramanik, A. H., Mohammed, M. O., Amin, M. F. B., \& Muhammad, A. D. (2015). Integration of waqf-Islamic microfinance model for poverty reduction. International Journal of Islamic and Middle Eastern Finance and Management, 8(2), 246 - 270. https://doi.org/10.1108/IMEFM-03-2014-0029

Hoexter, M. (1998). Waqf studies in the twentieth century: The state of the art. Journal of the Economic and Social History of the Orient, 41(4), 474-495. https:// doi.org/10.1163/1568520001445568

Ihsan, H., \& Ibrahim, S. H. H. M. (2011). Waqf accounting and management in Indonesian waqf institutions. Humanomics, 27(4), 252 - 269. http://dx.doi. org/10.1108/08288661111181305

Kachkar, O. A. (2017). Towards the establishment of cash waqf microfinance fund for refugees, ISRA International Journal of Islamic Finance, 9(1), 81-86. https://doi. org/10.1108/IJIF-07-2017-007

Kahf, M. (1999). Financing the development of awqaf property. The American Journal of Islamic Social Sciences, 16(4), 39-66.

Kahf, M. (2003). The role of waqf in improving the ummah's welfare. Paper presented at the International Seminar on Waqf as a Private Legal Body, 6-7 January, Islamic University of North Sumatra, Medan, Indonesia.

Kassim, S. (2016). Islamic finance and economic growth: The Malaysian experience. Global Finance Journal, 30, 66-76. https://doi.org/10.1016/j. gfj.2015.11.007

Kuran, T. (2001). The provision of public goods under Islamic law: Origins, impact, and limitations of the waqf system. Law and Society Review, 35(4), 841-898. https://doi.org/10.2307/3185418

Mahamood, S. M., \& Ab Rahman, A. (2015). Financing universities through waqf, pious endowment: is it possible? Humanomics, 31(4), 430-453. https://doi. org/10.1108/H-02-2015-0010

Mohsin, M. I. A. (2013). Financing through cash-waqf: a revitalization to finance different needs, International Journal of Islamic and Middle Eastern Finance and Management, 6(4), 304-321. https://doi.org/10.1108/IMEFM-08-2013-0094

Mokhtar, F.M., Sidin, E.M., \& Razak, D.A. (2015), Operation of cash waqf in Malaysia and its limitations. Journal of Islamic Economics Banking and Finance, 11(4), 100-114.

Mokhtar, S., Ibrahim, M., Omer, S., \& Osman, D. H. J. H. (2008, June). Issues, Problems and Strategies of Waqf Land Development in Malaysia-Literature Review. In 7th Annual Conference Management in Construction Researchers' Association MICRA, Kuala Lumpur (pp. 8-19).

Peri, O. (1992). Waqf and Ottoman welfare policy. Journal of the Economic and Social History of the Orient, 35(2), 167-186. https://doi.org/10.1163/156852092X00093 
Prihatini, F., Hasanah, U., \& Wirdyaningsih (2005), Hukum Islam zakat dan wakaf, teori dan prakteknya di Indonesia. Badan Penerbitan Fakultas Hukum Univesitas Indonesia, Jakarta.

Pritchard, A. (1969). Statistical bibliography or bibliometrics. J. Doc. 25(4), 348-349. Raghibi, A., \& Oubdi, L. (2018). Sukuk-Waqf: The Islamic Solution for Public Finance Deficits. European Journal of Islamic Finance, 9, 1-7. https://mpra.ub.unimuenchen.de/85629/

Sadeq, A. M. (2002). Waqf, perpetual charity and poverty alleviation. International Journal of Social Economics, 12(2), 135-151. https://doi. org/10.1108/03068290210413038

Sakti, T.S., \& Rani, L.N. (2020), Waqf and water crisis: The case of Paciran, Lamongan. Test Engineering and Management, 83, 3654-3662.

Salleh, M. C. M., Razali, S. S., Laksana, N. N. M., Embi, N. A. C., \& Abdullah, N. I. (2020). Developing a sustainable model of waqf-based takaful for flood victims in Malaysia. Journal of Islamic Accounting and Business Research, 12(4), 41-62. https://doi.org/10.1108/JIABR-10-2016-0114

Syahputra, A., \& Khalid, K. (2020). Sengketa tanah wakaf di Sumatera Utara (Systematic Literature Review Terhadap Pemberitaan Media Online). Halu Oleo Law Review, 4(1), 13-24.

Shaikh, S. A., Ismail, A. G., \& Shafiai, M. H. M. (2017). Application of waqf for social and development finance. ISRA International Journal of Islamic Finance, 9(1), 5-14. https://doi.org/10.1108/IJIF-07-2017-002

Shatzmiller, M. (2001). Islamic institutions and property rights: The case of the 'public good' Waqf, Journal of the Economic and Social History of the Orient, 44(1), 44-74. https://doi.org/10.1163/156852001300079148

Shukor, S. A., Anwar, I. F., Sabri, H., Aziz, S. A., \& Ariffin, A. R. M. (2017). Giving behaviour: Who donates cash waqf Malaysian. Journal of Consumer and Family Economics, 87-100.

Suhaimi Nahar, H., \& Yaacob, H. (2011) Accountability in the sacred context: the case of management, accounting and reporting of a Malaysian cash Awqaf institution. Journal Of Islamic Accounting And Business Research, 2(2), 87-113. https://doi.org/ 10.1108/17590811111170520

Sulaiman, S., Hasan, A., Mohd Noor, A., Ismail, M. I., \& Noordin, N. H. (2019). Proposed models for unit trust waqf and the parameters for their application. ISRA International Journal of Islamic Finance, 11(1), 62-81. https:// doi.org/ 10.1108/IJIF-02-2018-0019

Wu, T. H. (2017). From waqf, ancestor worship to the rise of the global trust: A history of the use of the trust as a vehicle for wealth transfer in Singapore. Iowa Law Review, 103, 22-63.

Yayla, H. E. (2011). Operating regimes of the government: Accounting and accountability changes in the Sultan Süleyman Waqf of the Ottoman Empire (The 1826 Experience), Accounting History, 16(1), 5-34. https://doi. org/10.1177/1032373210389320

Yaakob, A., Mahzir, N., \& Supaat, D.I. (2017). Waqf as a means of forest conservation: Alternative for Malaysia. Advanced Science Letters, 23(5), 4860-4864. https://doi. org/10.1166/asl.2017.8928 
Yusof, M. F. M., Yusof, M. F. M., Hasarudin, M. H., \& Romli, N. (2014). Cash waqf and infaq: A proposed e-philanthropy in Malaysia. Jurnal Kemanusiaan, 12(1), 1-10.

Yaacob, H., (2013). Waqf history and legislation in Malaysia: A contemporary perspective. Journal of Islamic and Human Advanced Research, 3(6), 387-402.

Zhang, D., Zhang, Z., \& Managi, S. (2019). A bibliometric analysis on green finance: Current status, development, and future directions. Finance Research Letters, 29, 425-430. https://doi.org/10.1016/j.frl.2019.02.003 
This page is intentionally left blank 